Viso - Cadernos de estética aplicada Revista eletrônica de estética

ISSN 1981-4062

No 13, jan-jun/2013

http://www.revistaviso.com.br/

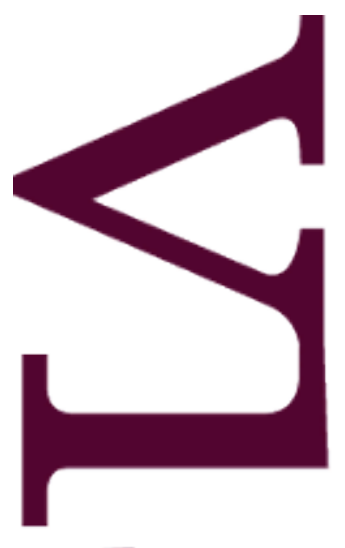

$m$

r

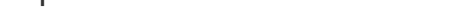

\title{
Horses Hotel: Proust a Contrapelo Patrick Bange
}




\section{RESUMO}

\section{Horses Hotel: Proust a Contrapelo}

Este trabalho articula uma crítica da peça Horses Hotel, dirigida por Alex Cassal e Clara Kutner e que esteve em cartaz no Oi Futuro do Flamengo, no Rio de Janeiro, de dezoito de abril a dois de junho de 2013. A partir de uma investigação do projeto estético disposto sobre o palco, percurso ao longo do qual convido Gustave Flaubert e Marcel Proust, discuto em que medida esse projeto constitui uma estética sintomática, cuja base está na defesa de uma arte pela sensação em si.

Palavras-chave: crítica teatral - Gustave Flaubert - Marcel Proust - sensação

\section{ABSTRACT}

\section{Horses Hotel: Proust Against the Grain}

This paper articulates a review of Horses Hotel, a play directed by Alex Cassal and Clara Kutner, which has been staged in Oi Futuro Theater, in Flamengo, Rio de Janeiro, from 18th April to 2nd June 2013. Starting from an investigation on the esthetic project arranged on stage, I invite Gustave Flaubert and Marcel Proust to discuss in which way this project consists in a symptomatic aesthetic based on the defense of a sensationitself's art.

Keywords: theater criticism - Gustave Flaubert - Marcel Proust - sensation 
BANGE, P. "Horses Hotel: Proust a Contrapelo". In: Viso: Cadernos de estética aplicada, v. VII, n. 13 (janjun/2013), pp. 1-8.

DOI: 10.22409/1981-4062/v13i/147

Aprovado: 29.06.2013. Publicado: 29.10.2013.

(C) 2013 Patrick Bange. Esse documento é distribuído nos termos da licença Creative Commons Atribuição-NãoComercial 4.0 Internacional (CC-BY-NC), que permite, exceto para fins comerciais, copiar e redistribuir o material em qualquer formato ou meio, bem como remixá-lo, transformá-lo ou criar a partir dele, desde que seja dado o devido crédito e indicada a licença sob a qual ele foi originalmente publicado.

Licença: http://creativecommons.org/licenses/by-nc/4.0/deed.pt_BR

Accepted: 29.06.2013. Published: 29.10.2013.

(C) 2013 Patrick Bange. This document is distributed under the terms of a Creative Commons Attribution-NonCommercial 4.0 International license (CC-BY-NC) which allows, except for commercial purposes, to copy and redistribute the material in any medium or format and to remix, transform, and build upon the material, provided the original work is properly cited and states its license.

License: http://creativecommons.org/licenses/by-nc/4.0/ 
O tempo é chave decisiva na peça Horses Hotel, dirigida por Alex Cassal e Clara Kutner, que esteve em cartaz no Oi Futuro do Flamengo, de dezoito de abril a dois de junho de 2013. O espetáculo se inicia com o gesto de uma atriz, Ana Kutner, que divide o palco, no escuro, com mais três atores, Renato Linhares, Emanuel Aragão e Roberto Souza. Ela, que encarnará a máscara fixa de uma poeta, liga a luz de um retroprojetor, diante da qual diz suas primeiras palavras. Essa cena inaugura o primeiro, e também fundador, tempo da peça. Fundador porque instala o final da linha de uma colcha de retalhos, isto é, o ponto, in ficção, cronologicamente mais avançado entre os vários pontos que serão evocados à cena, pois os retalhos vão sendo encenados, um a um, emendados um no outro, ao longo da peça. Nesse último ponto, a poeta é, dentre os principais personagens reconhecíveis do enredo, a única sobrevivente de um projeto estético. Ela fala a respeito "dele", um fotógrafo, com quem tivera uma relação amorosa e com quem dividira um quarto no Horses Hotel:

Aquela parede [pausa] era coberta de fotos. Era o nosso santuário. Com todas as nossas divindades reunidas. Todos aqueles que nos protegiam e inspiravam. A cama tava sempre desarrumada. Passávamos muito tempo na cama. Comendo, dormindo, trepando, lendo, escrevendo, trabalhando.

Depois da fala, o ator, que fará o fotógrafo, deitado na cama, quebra o tempo em que a poeta está, estourando a bolha com uma fala que a convida a voltar à cama. Nisso, a poeta se junta a ele, já nesse segundo tempo. Ele pede a ela que conte uma história, ao que se seguem os primeiros flashes narrados: uma história com Janis Joplin, outra com Andy Warhol, outra com uma menina que morreu de leucemia. Como considera essa última história horrível, ele a provoca, "vai, garoto encontra garota, noite de verão". Ela completa, "noite de verão de uma segunda-feira", ao que se segue mais um tempo da peça, mais um dos clicks de uma máquina fotográfica. O garoto e a garota, sabemos depois, são eles mesmos. Ao fim do espetáculo, fica visível que a plateia está diante de um álbum de fotos polaroides composto pela poeta, depois da morte do fotógrafo. Em termos têxteis, o método para o preenchimento desse álbum é o de alguém que recorta a linha do tempo, distribuindo pedaços, de maneira mais ou menos arbitrária, e os cola sobre a superfície do palco. O que justifica essa percepção é o fato de que, próximo ao fim da peça, a voz da poeta, a mesma do início, retorna à cena, no mesmo tom, dizendo, "Tínhamos 17 anos. Às vezes, saíamos pra caminhar à noite", uma fala-relâmpago em que vejo a autora do álbum retornar ao tempo "presente", o mesmo do início da peça. Não fosse pela cena final, bem próxima dessa fala, quando a poeta expõe a sua arte num show de rock - em que canta a música Horses, de Patti Smith, e encarna o personagem Johnny de sua letra, no texto mais imagético da peça - não fosse pelo show, a peça começaria e terminaria com o tom melancólico da poeta-narradora, ou com o beijo (de despedida?) entre ela e ele. Nesse sentido, certamente pela defesa de uma arte que procure sentido na sensação, a peça termina com o show, com muita música e performance, e não com a angústia da poeta, cuja afinidade com a morte põe em xeque os acontecimentos anteriores ao momento da primeira fala da peça. Leio o que Erich 
Auerbach, no clássico Mimesis, escreve sobre Emma Bovary, protagonista do romance de Flaubert:

A estufa que fumegava, a porta que rangia, os muros que transudavam, as lajes úmidas: certamente Emma sente e vê tudo isto, mas ela não seria capaz de ajuntá-lo dessa forma. Toda a amargura da existência parecia-Ihe servida em seu prato: ela certamente tem uma tal sensação, mas se quisesse exprimi-la, não o faria desta forma; para chegar a esta formulação faltam-lhe a agudeza e a fria honestidade que resulta de uma prestação de contas consigo mesmo. ${ }^{1}$

Falta à poeta, que também é narradora em cena, essa mesma prestação de contas? Pouco antes da fala "eu tinha dezessete anos", a morte do fotógrafo estava próxima. Ela diz, "tô terminando um disco novo", ele, "cê acha que vai dá tempo d'eu ouvir?", e ela, "detesto essa história de você morrer antes de mim". As primeiras palavras da peça dão um sentido terrível a esse diálogo, porque anunciam os restos mortais de um posicionamento estético. Por essa via crítica, a peça deve ser entendida como o esforço da poeta em revisitar as experiências vividas pelos dois. O álbum cênico, isto é, o palco, coloca esse esforço em movimento, diante do público. Resta perguntar em que a poeta se refugia, depois da morte do fotógrafo. Duas questões, nesse sentido, parecem relevantes: a paixão e a arte, indissociáveis.

Arte é como estar apaixonado, é esperar alguém chegar, é acordar ao meio-dia e não saber que dia é hoje, é começar uma vida junto. [...] Arte é ter insônia, ficar fumando na varanda e ver o mundo mudando junto com o letreiro luminoso. É como ver pela janela aberta do prédio, do outro lado da rua, a beleza de um casal adolescente que já fez as malas, que já fez amor e agora dorme.

Arte para a poeta, como para a peça, é, antes de tudo, uma experiência a que se está submetido. Curioso pensar que arte é "acordar ao meio-dia". Acordar tarde também significa ter ido dormir tarde, também significa ter experimentado da vida sensações que não cabem, pelo menos no tempo fora da peça, por exemplo, num regime profissional, que nos obriga a acordar às seis da manhã, ou antes. Mas o tempo da ficção é outro e remonta, provavelmente, aos anos 60 ou 70, na Europa ou nos Estados Unidos, já que há um aquecedor no cenário. Falo do tempo fora da peça porque também isso compõe a opção estética que a determina: por que montar um cenário que nos transporta radicalmente para um contexto alheio ao nosso? De qualquer maneira, para os artistas da peça, arte é transfiguração de uma realidade dada, a do "letreiro luminoso", em outra, a princípio mais visceral, porque mais íntima do corpo. O exemplo categórico é o corpo nu de um personagem chamado Theo, o michê que foi um amor do fotógrafo e da poeta. No palco, o corpo nu implora, "me fotografa, me fotografa, me transforma numa obra de arte". O que é interessante perceber é que o corpo nu fotografado daria a Theo, que agora, na peça, está sozinho, um razão para estar vivo. Portanto, a um mesmo tempo, o apelo ao corpo é uma promessa de salvação e um aprisionamento. O modo como o ator Emanuel Aragão interpreta a loucura de Theo dá bem a medida dessa ambivalência. 
O fotógrafo, mais à frente, pergunta, "tá bom, arte é como estar apaixonado, mas como transcender o conceito e se tornar arte?". Em outros termos, se os limites da arte estão no plano da ação sensível (se apaixonar, acordar, fumar, ver, fazer amor), a questão é: como fazer arte? Ou: o que é arte? A solução da peça sugere um atravessamento. Diz a poeta, "é como atravessar portas, é como a música do Doors, break on through to the other side", então, Theo, pra atravessar pro outro lado, basta passar por uma porta", e o fotógrafo completa:

Uma porta não é suficiente, você tem que atravessar um mar de portas. Tem que ir além. Além do espelho, além do reflexo, além do além. Ninguém tinha feito, alguém precisava fazer. O nome disso é vanguarda [a plateia ri]. Alguém precisava enfiar um cabo de vassoura no ânus da arte.

"Um mar de portas" conjuga com "um mar de possibilidades", dois mares que nos chegam aos ouvidos pela boca do fotógrafo, para quem arte é como penetrar um "cabo de vassoura no ânus da arte". Assim, a arte está altamente associada ao coito e mesmo ao estupro. Um professor meu me contou, acho que em 2008, que foi com um cabo de vassoura no ânus que a inquisição espanhola assassinou Garcia Lorca. Minha associação, naturalmente, não é gratuita. Dizer que a verdadeira arte é "ir além do além", e que fazer arte é "enfiar um cabo de vassoura no ânus da arte" constitui os moldes de uma estética submetida a apelos sinestésicos, estranhamente associáveis às violências da inquisição espanhola, como das ditaduras modernas. Em todos esses casos, a faceta animal do humano, comum a toda a gente, está no comando.

Qual, então, o saldo da busca da poeta, ao revisitar seu passado com o fotógrafo? E qual o saldo da sua reflexão estética? Temos, de maneira mais ou menos objetiva, um dramaturgo, amor da poeta, que desaparece como um cowboy, Theo morto, Sam morto (o último dos amores do fotógrafo, a quem, parece, passa AIDS) e o fotógrafo morto. Há uma passagem que parece ilustrar o lugar que sobra para a poeta, logo depois que o dramaturgo a deixa: por volta da metade da peça, ela afirma, em tom mais uma vez parecido com o do início da peça, "tô sozinha. Tô batendo a cabeça na parede do lado do quarto. De madrugada". Nisso, a poeta está no centro do palco, iluminada, de novo, pela luz do retroprojetor. Um ator vai limitando a luz, com pedaços de papel, até que só sobra o olho da poeta, encurralado na escuridão. O saldo, então, é o de alguém que procurou estar sujeito a uma experiência e, depois que ela acaba, sofre. Eis um resumo do resultado da procura da poeta:

Eu não quero ser entendida. Eu quero que as pessoas sintam, quero entrar debaixo da pele das pessoas como uma larva e deixar lá meus ovos.

Para voltar a Flaubert, os saldos da busca da poeta e da busca de Emma Bovary são bem semelhantes, já que também Emma fica cercada de mortes: a do dinheiro de seu marido, a da possibilidade de um amor autêntico, a da capacidade de sair de sua própria lama. Uma diferença central, entretanto, é que Flaubert mata Emma. Quando Auerbach 
delata a chave da interpretação de Emma como a de uma personagem que não alcança a manifestação linguística de suas angústias, ele justifica também a necessidade de sua morte, que é, ao longo do Madame Bovary, uma morte sempre anunciada. Sendo assim, a deixa do crítico antecipa uma compreensão de Marcel, narrador de Em busca do tempo perdido, de Proust, que é esse narrador que, segundo Deleuze, em Proust e os signos, parece ter os seus esforços voltados à elaboração do aprendizado de tornar-se escritor. Ser escritor, concluo, é o produto, nas palavras de Auerbach, da "prestação de contas consigo mesmo", que, se falta à Emma Bovary, é uma das colunas vertebrais de Em busca do tempo perdido. O procedimento teórico de Deleuze, por sua vez, denuncia que a chave do romance de Proust não está nem na memória, nem no passado, mas na busca de um aprendizado artístico, que se confunde, posso dizer, com a prestação de contas consigo mesmo. Mas que tem isso a ver com Horses Hotel?

Jeanne-Marie Gagnebin, no ensaio O rumor das distâncias atravessadas, que não deixa de ser um desdobramento da deixa deleuziana, compara Jean Santeuil e Em busca do tempo perdido, dois romances de Proust, sendo o primeiro anterior ao segundo. JeanneMarie se refere à sensação despertada pelo gosto da célebre madeleine:

Para ele [Proust], não se trata de escrever um romance de impressões seletas e felizes, mas sim de enfrentar, por meio da atividade intelectual e espiritual que o exercício da escrita configura, a ameaça do esquecimento, do silêncio e da morte. Em outras palavras: não é a sensação em si (o gosto da Madeleine e a alegria por ele provocada) que determina o processo da escrita verdadeira, mas sim a elaboração dessa sensação, a busca espiritual do seu nome originário, portanto, a transformação, pelo trabalho da criação artística, da sensação em linguagem, da sensação em sentido. ${ }^{2}$

As palavras de Jeanne-Marie dão margem ao entendimento de que a estética das sensações da poeta, como da peça, faz com que essas mesmas sensações permaneçam a meio caminho do sentido, justamente por advogar uma arte da "sensação em si". Por isso, a fala inicial da poeta não alcança uma perspectiva de futuro, como acontece com Marcel, que pode se tornar escritor depois dos sete volumes de Em busca do tempo perdido. Ela, nesse sentido, está diante de um álbum triste e cercada de silêncio, paralisada diante de distâncias não atravessadas e, paradoxalmente, de um mar de portas. Por que um mar de portas? Por que tantas possibilidades? Parece ficar claro que a plateia está diante de uma estética sintomática. $\mathrm{O}$ apelo, o exagero, nesse sentido, não estão no lugar de uma opção, mas à mercê de um não-sentido, ou de um sentidoquase, que constitui, em si, uma busca, ou uma tentativa. Mas uma tentativa que gozou fora de uma vagina fértil.

Walter Benjamin, no belíssimo ensaio $A$ imagem de Proust, desenha, num autêntico exercício de pintura, sobre a tela que é Em busca do tempo perdido, a seguinte imagem:

Pois o importante, para o autor que rememora, não é o que ele viveu, mas o tecido de sua rememoração, o trabalho de Penélope da reminiscência. Ou seria preferível falar do trabalho de Penélope do esquecimento? A memória involuntária, de Proust, não está 
mais próxima do esquecimento que daquilo que em geral chamamos de reminiscência? Não seria esse trabalho de rememoração espontânea, em que a recordação é a trama e o esquecimento a urdidura, o oposto do trabalho de Penélope, mais que sua cópia? Pois aqui é o dia que desfaz o trabalho da noite. ${ }^{3}$

Talvez esteja faltando à trama dos fios da peça, em que sobra nas mãos da poeta o último fio, essa permissão tão difícil: a linha mestra de um esquecimento criador.

* Patrick Bange é graduando em letras pela UFRJ.

1 AUERBACH, E. Mimesis: a representação da realidade na literatura ocidental. São Paulo: Perspectiva, 2009, p. 434. Tradução dos trechos de Madame Bovary: Fúlvia M. L. Moretto, in: FLAUBERT, G. Madame Bovary: costumes de província. São Paulo: Nova Alexandria, 2007.

${ }^{2}$ GAGNEBIN, J. M. Lembrar Escrever Esquecer. São Paulo: Editora 34, 2006, p. 154. Grifo meu.

${ }^{3}$ BENJAMIN, W. Magia e técnica, arte e política: ensaios sobre literatura e história da cultura. Tradução de Sergio Paulo Rouanet. São Paulo: Brasiliense, 1994, p. 37. Grifo meu. 